\title{
Two new species of Andean gymnophthalmid lizards of the genus Euspondylus (Reptilia, Squamata) from central and southern Peru
}

\author{
Germán Chávez ${ }^{1, \dagger}$, Karen Siu-Ting ${ }^{2, \ddagger}$, Vilma Duran ${ }^{1, \S}$, Pablo J Venegas ${ }^{1, \pi}$ \\ I División de Herpetología, Centro de Ornitología y Biodiversidad (CORBIDI), Santa Rita N¹05 Of. 202, \\ Urb. Huertos de San Antonio, Surco, Lima, Perú 2 Dpto. de Herpetología, Museo de Historia Natural, Uni- \\ versidad Nacional Mayor de San Marcos, Lima, Perú \\ † urn:lsid:zoobank.org:author:9E8C7BD7-4A1B-469D-B54B-AE16D8DA2DD4 \\ $\ddagger$ urn:lsid:zoobank.org:author:32EBBOFC-DOEE-478B-A83B-D729AF557396 \\ § urn:lsid:zoobank.org:author:63A4BEBE-73D5-4B7D-A091-ECACD35447F6 \\ I urn:lsid:zoobank.org:author:15AD03E1-9ACF-4F38-AA96-09A5A56A3DC4 \\ Corresponding author: Germán Chávez (vampflack@yahoo.com) \\ Academic editor: Hans-Dieter Sues | Received 25 March 2011 | Accepted 20 May 2011 | Published 20 June 2011 \\ urn:lsid:zoobank.org:pub:143BD829-EC69-4485-9BDB-EC6D0F816B1C \\ Citation: Chávez G, Siu-Ting K, Duran V, Venegas PJ (2011) Two new species of Andean gymnophthalmid lizards \\ of the genus Euspondylus (Reptilia, Squamata) from central and southern Peru. ZooKeys 109: 1-17. doi: 10.3897/ \\ zookeys.109.1304
}

\begin{abstract}
Two new species of lizards assigned to the genus Euspondylus from the montane forests of the Peruvian Andes in the Pasco Department (central Peru) and Ayacucho Department (southern Peru) both at elevations of 2550 and $3450 \mathrm{~m}$, respectively, are described. The new species are distinguishable from all other Peruvian and Ecuadorian species of Euspondylus by a unique combination of morphometric, scalation and color pattern characteristics. Natural history data for the new species and for E. spinalis are also provided.

\section{Resumen}

Se describe dos especies nuevas de lagartijas asignadas al género Euspondylus de los bosques montanos de los Andes de Perú: una del Departamento de Pasco (centro de Perú) y otra del Departamento de Ayacucho (sur de Perú), ambas a 2550 y $3450 \mathrm{~m}$ de altitud, respectivamente. Las nuevas especies se distinguen de las otras especies peruanas y ecuatorianas de Euspondylus por una combinación única de características morfométricas, escamación y patrón de coloración. Además, se presenta datos de historia natural para las nuevas especies y E. spinalis.
\end{abstract}

Copyright Germán Chávez et al. This is an open access article distributed under the terms of the Creative Commons Attribution License, which permits unrestricted use, distribution, and reproduction in any medium, provided the original author and source are credited. 


\section{Keywords}

Euspondylus, Gymnophthalmidae, Peru, new species

\section{Introduction}

The family Gymnophthalmidae comprises about 36 genera and 160 species of small lizards with elongated thin bodies and relatively short limbs, which are reduced in various degrees in some species and nearly absent in others (Pianka and Vitt 2003). These New World lizards are primarily limited to tropical latitudes, but gymnophthalmid diversity is high in both the lowland Amazonian forest and foothills and the valleys and hillsides of the Andes (Presch 1980). Some species in the genera Euspondylus, Opipeuter, Pholidobolus, Petracola, Proctoporus and Riama even reach high elevation in the Andes, such as Proctoporus bolivianus that can be found at $4080 \mathrm{~m}$ elevation (Doan and Castoe 2003) in the Peruvian Andes.

Eleven species are currently assigned to Euspondylus. These small secretive lizards are distributed along the Andes and Tepuis between Venezuela and southeastern Peru (Mijares-Urrutia et al. 2001; Köhler 2003; Köhler and Lehr 2004). The highest diversity of the genus Euspondylus occurs in Peru with eight species: E. caideni Köhler, E. guentheri (O'Shaughnessy), E. josyi Köhler, E. maculatus (Tschudi), E. nellycarrillae Köhler and Lehr, E. rahmi (De Grijs), E. simonsii (Boulenger), and E. spinalis (Boulenger), all of these with distributions restricted to a few localities with elevations ranging from 800-3310 m (Mijares-Urrutia et al. 2001; Köhler 2003; Köhler and Lehr 2004).

The taxonomy of Euspondylus is problematic due to the unclear generic diagnosis and species assignations with members of the genus Proctoporus. According to the traditional generic diagnosis by Peters and Donoso-Barros (1970), Euspondylus is characterized by the presence of anterior nasal scales separated by rostral and frontonasal scales, and prefrontal and dorsal scales that are not granular, whereas Proctoporus lacks prefrontal scales and has either keeled or striated dorsal scales. Kizirian (1996) reviewed the species then referred to Proctoporus from Ecuador (all of which were later assigned to a resurrected genus Riama by Doan and Castoe 2005) and corroborated the separation of both genera by the presence (in Euspondylus) and absence (in Proctoporus) of prefrontal scales. Köhler and Lehr (2004) recognized much variation in the presence of prefrontal scales in Euspondylus spinalis from Peru, and suggested that the presence versus absence of prefrontal scales is not a determining character for the separation of Proctoporus and Euspondylus, questioning the separation of the two genera. Doan and Castoe (2005) separated two genera from Proctoporus: Riama and Petracola; however, they never addressed the taxonomic distinction between the three genera and Euspondylus. Therefore, until a new and well supported classification of the Andean gymnophthalmids is proposed, we follow the generic diagnosis by Peters and Donoso-Barros (1970) and Doan and Castoe (2005) to distinguish between Euspondylus, Proctoporus, Petracola and Riama. 
Recent herpetological surveys in the central and southern Andes of Peru resulted in the discovery of two new species of gymnophthalmids, which are described and tentatively assigned to the genus Euspondylus.

\section{Materials and methods}

The format for the description of the new species generally follows that of Köhler and Lehr (2004). For the comparisons only Ecuadorian, Peruvian, and Bolivian species of Euspondylus, Opipeuter, Petracola, Proctoporus and Riama were included because our purpose was to distinguish the two new species from any that could occur in sympatry or be similar. Nomenclature of scale characters follows that of Köhler and Lehr (2004). Scale sizes were measured using precision calipers and were rounded to the nearest 0.1 $\mathrm{mm}$. For characters recorded on both sides, the condition on the right side is presented first. Everted hemipenes were fixed with formalin 10\%. Abbreviations for museum collections are as follows: CORBIDI (Centro de Ornitología y Biodiversidad) and MUSM (Museo de Historia Natural Universidad Nacional Mayor de San Marcos, Lima, Peru) and GPS coordinates were taken using the geodetic datum WGS84.

\section{Results}

\section{Euspondylus chasqui sp. $\mathrm{n}$.}

urn:lsid:zoobank.org:act:D08B998E-CAAD-4648-AA13-DB7AEE1C0250 http://species-id.net/wiki/Euspondylus_chasqui

Figs $1-2$

Holotype. (Fig. 1a) Adult male (CORBIDI 06963), Perú, Ayacucho Department, La Mar Province, Chiquintirca (1301'59.7”S; 7340'46.0”W), 2780 m elevation, collected by Germán Chávez on 24 August 2010.

Paratypes. (Fig. 1b-d) CORBIDI 06955, 06966, 06968-69 (all adult females), 06961-62, 06965, 06967 (all adult males), 06964 (juvenile), same data as holotype; CORBIDI 08413, 08415-16, 08418-19, 08423 (all adult males), 08414, 08417, 08420-22, 08424-25, 08431-32 (all adult females), Perú, Ayacucho Department, La Mar Province, surroundings of Chiquintirca (1301'17.4”S; 7340'30.1”W), $2598 \mathrm{~m}$ elevation, collected by Vilma Duran and Karla García on 18 December 2010.

Diagnosis. 1) Head rounded in dorsal and lateral view, frontonasal length usually equal or slightly larger than frontal length; (2) nasoloreal suture present; (3) supraoculars four, anteriormost supraocular fused with anteriormost superciliary, all supraoculars separated from ciliaries; (4) superciliary series complete, five; (5) supralabial-subocular fusion absent; (6) postoculars three; (7) postparietals three; (8) supratympanic temporals three; (9) genials in two pairs, transverse sutures perpendicular with respect to midline of body; (10) dorsal scales rectangular, juxtaposed, keeled; (11) transverse 

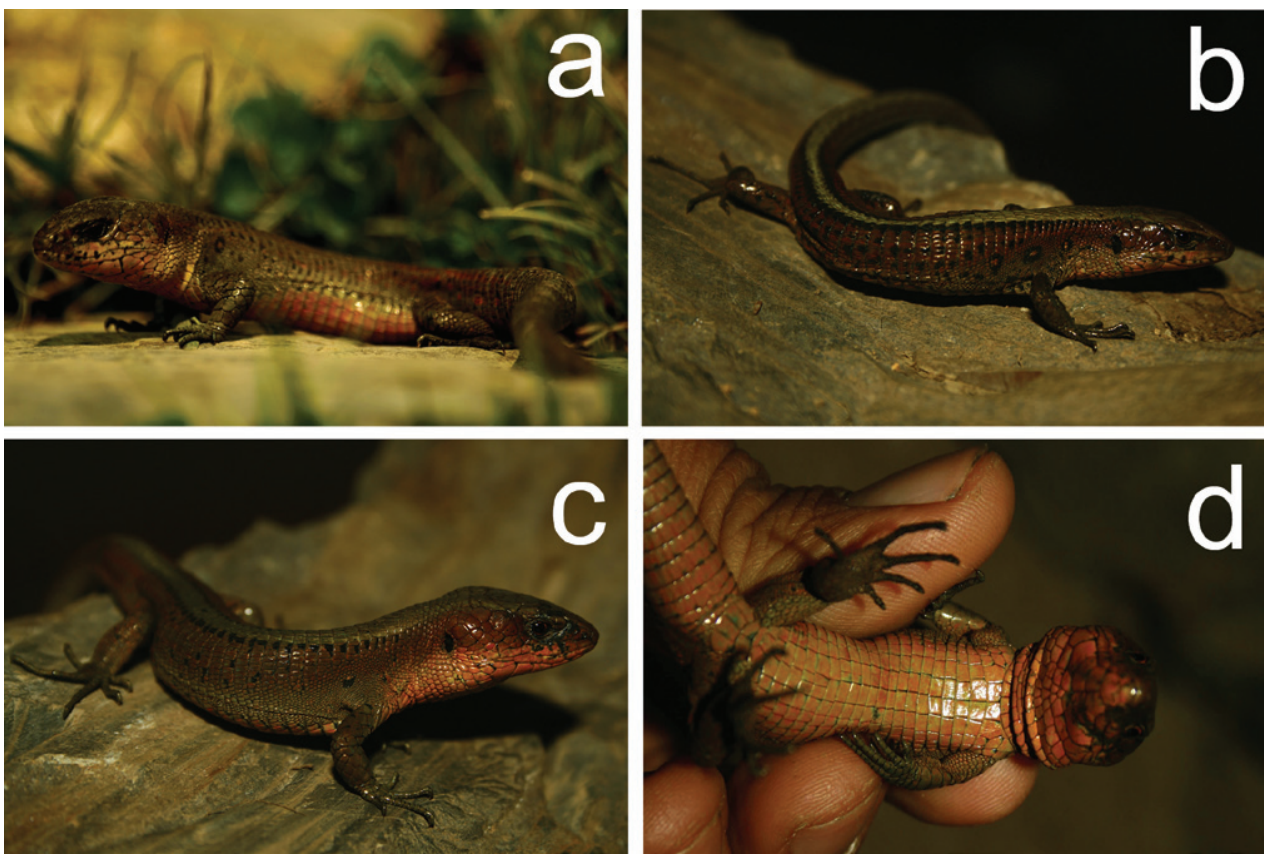

Figure I. Euspondylus chasqui, new species, from southeastern Peru. Holotype male (CORBIDI 06963, a); female (CORBIDI 06961, b); and male (CORBIDI 06969, c, d).

dorsal count (enlarged rows at midbody) at midbody 20-28 in both sexes; (12) longitudinal dorsal count 35-43 in both sexes; (13) longitudinal ventral count 19-22 in both sexes; (14) lateral scale rows at midbody two or three; (15) femoral pores in males $8-11$, in females 7-10; two scales between femoral pores; (16) subdigital scales on 4th finger 10-16, on 4th toe 17-26; (17) limbs overlapping, pentadactyl; digits clawed; forelimb reaching anteriorly to fourth supralabial; (18) anterior preanal plate scales paired; (19) hemipenis acapitate; flounces lacking calcified spines and forming two chevrons on distal half of hemipenis whereas basal half is covered with three transverse flounces; some asulcate flounces separated by a small expansion pleat; sulcate flounces about as wide as asulcate flounces; sulcus spermaticus single, flanked by a broad naked expansion pleat widened distally; (20) dorsum olive green, brown, or reddish brown with a middorsal pale stripe bordered by a discontinous dark line on neck and body more prominent in females than males; lateral ocelli present; ventral surfaces yellowish or reddish white; (21) transparent lower palpebral disc an undivided oval; (22) prefrontals present.

Euspondylus chasqui can be distinguished from other Peruvian species currently assigned to Euspondylus by the following character states (condition for E. chasqui in parentheses). E. maculatus and E. guentheri: a lower palpebral disc with vertical sections (palpebral disc an undivided oval), dorsal scales smooth or wrinkled (keeled), and longitudinal dorsal count 32-37 (35-43). E. caideni: by three or four superciliaries (five superciliaries), pale middorsal stripe absent (present), lateral ocelli absent (present), 

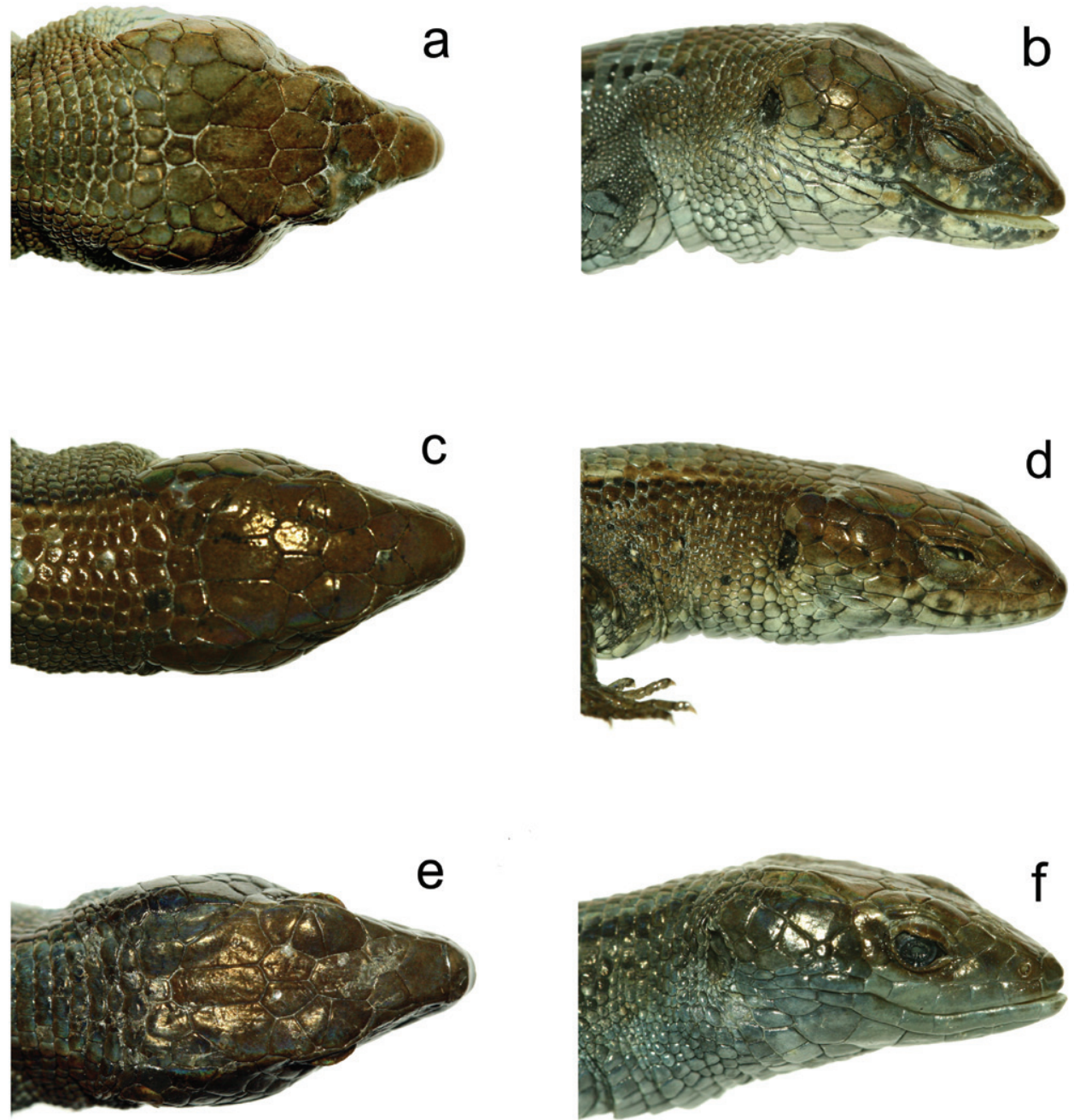

Figure 2. Heads of various species of Euspondylus. Holotype of Euspondylus chasqui (CORBIDI 06963, a,b), holotype of Euspondylus oreades (CORBIDI 07219, c,d) and Euspondylus spinalis (CORBIDI 07234, e,f).

dorsal scales reduced in size above longitudinal band of laterals granules (not reduced), longitudinal dorsal count 41-48 (35-43). E. josyi: by having three supraoculars, exceptionally four, (four supraoculars), pale vertebral stripe absent (present), lateral ocelli absent (present), limb overlapping 10-13 dorsal scales (10-12), longitudinal dorsal count 29-35 (35-43) and SVL to $62.0 \mathrm{~mm}(74.0 \mathrm{~mm})$. E. rahmi: anteriormost supraocular not fused with anterior most superciliary (fused), longitudinal dorsal count 49-54 (35-43), dorsal scales reduced in size above longitudinal band of laterals granules (not reduced) and maximum SVL $71.0 \mathrm{~mm}(74.0 \mathrm{~mm})$. E. simonsii: a pale line between the tympanum and shoulder present (absent), dorsal scales smooth or only faintly keeled on posterior dorsum (all dorsal scales keeled), longitudinal dorsal count 
33-39 (35-43) and transversal count at midbody less than 35 (40-48). E. spinalis: head acuminate from the dorsal and lateral view (rounded), prefrontals present or absent (prefrontals present), adpressed limbs overlapping by fewer than 10 dorsal scales rows (adpressed limbs overlapping by 10-12 dorsal scale rows), dorsal scales reduced in size above longitudinal band of laterals granules (not reduced), longitudinal dorsal count 39-46 (35-43), femoral pores on one side in females 1-6 (8-10) and small SVL, according to a population from Oso Playa, Pasco Department, ranging between 44.0-55.0 mm (SVL ranging between $50.7-74.0 \mathrm{~mm}$ ). E. nellycarrillae: dorsal scales subhexagonals (rectangular), and longitudinal dorsal count 41-49 (35-43), femoral pores of one side 12-15 in males, 12-14 in females (7-10 in females, 8-11 in males), and maximum SVL $=60.0 \mathrm{~mm}(74.0 \mathrm{~mm})$.

Euspondylus chasqui can be distinguished from all species currently assigned to Petracola, Proctoporus and Riama by the presence of prefrontal scales (absent in all species in these three genera). E. chasqui can be further distinguished by the following character states (condition for E. chasqui in parentheses). All Bolivian and Peruvian species of Proctoporus except $P$. pachyurus and $P$. bolivianus: longitudinal dorsal count fewer than 36 scale rows (35-43 scale rows). P. pachyurus: longitudinal dorsal count 49-59 scale rows (35-43 scale rows). P. bolivianus: $4-8$ femoral pores in males (7-11 femoral pores). All Petracola and Riama species: lower palpebral disc with vertical sections (palpebral disc an undivided oval). Northern Ecuador species of Riama excluding $R$. columbiana: no band of granular scales along the sides of body between dorsal and ventral scales (granular scales present). $R$. columbiana: limbs not overlapping when adpressed against body in adults (limbs overlapping), superciliary series incomplete (complete), and some supraoculars in contact with ciliaries (all supraoculars separated from ciliaries).

Euspondylus chasqui can be distinguished from Opipeuter xestus (condition for E. chasqui in parentheses): smooth dorsal scales (keeled); a single large elongate subocular (several small subocular scales); and in hemipenis morphology, large spines at the base of the sulcus spermaticus (no such spines present in E. chasqui).

Description of the holotype. Adult male (CORBIDI 06963) (Fig. 1a, 2a,b); SVL $=73.0 \mathrm{~mm}$, tail (complete) length $=124.0 \mathrm{~mm}$; axilla to groin distance $31.4 \mathrm{~mm}$; head length $20.2 \mathrm{~mm}$; head width $13.8 \mathrm{~mm}$; shank length $10.7 \mathrm{~mm}$.

Head scales smooth, glossy; rostral scale wider $(3.2 \mathrm{~mm})$ than long $(1.6 \mathrm{~mm})$, higher than adjacent supralabials, in contact with frontonasal, nasoloreal, and first supralabials posteriorly; frontonasal slightly longer $(3.5 \mathrm{~mm})$ than wide $(3.4 \mathrm{~mm})$, widest posteriorly, in contact with nasoloreal and frenocular laterally, prefrontals posteriorly; nasoloreal suture present; prefrontals present, in contact with each other medially, in contact with fused anteriormost superciliary-anteriormost supraocular, frontal posteriorly; frontal longer $(3.7 \mathrm{~mm})$ than wide $(3.0 \mathrm{~mm})$, anterior suture angular with point directed anteriorly, lateral sutures straight, posterior suture angular with point slightly directed posteriorly, in contact with second and third supraoculars laterally, frontoparietals posteriorly; frontoparietals pentagonal, in contact with third and fourth supraocular, parietals and interparietal posteriorly; supraoculars four, none in 
contact with ciliaries; superciliary series complete, anteriormost superciliary fused with anteriormost supraocular; interparietal heptagonal, longer $(4.8 \mathrm{~mm})$ than wide $(2.7$ $\mathrm{mm}$ ), in contact with parietals laterally, postparietals posteriorly; parietals polygonal, in contact with fourth supraocular anterolaterally, temporal scales laterally, dorsalmost postocular, postparietals posteriorly; postparietals three, lateral postparietals polygonal, medial postparietal squarish; palpebral disc an undivided oval, unpigmented; frenocular squarish, in contact with nasoloreal anteriorly; postoculars three; temporals polygonal; supratympanic temporals three; supralabials seven; infralabials five; mental wider $(2.9 \mathrm{~mm})$ than long $(1.5 \mathrm{~mm})$, in contact with first infralabials, postmental posteriorly; postmental single, pentagonal, posterior suture angular, point directed posteriorly, in contact with first and second infralabials; genials in two pairs, anterior pair subquadrangular, in contact with second and third infralabials; posterior genials subpentangular, in contact with fourth and fifth infralabials laterally; scale rows between genials and collar fold (along midventral line) 12; medialmost scales of three penultimate gular scale rows slightly enlarged; posteriormost gular row enfolded posteriorly, concealing two granular scale rows; lateral neck scales rounded, smooth.

Dorsal scales rectangular, longer than wider, juxtaposed, keeled, 40 in a longitudinal count; some middorsal scales irregularly arranged; transverse dorsal count (enlarged rows at midbody) at fifth transverse ventral scale row 16, at 10th transverse ventral scale row 29 , at 15 th transverse ventral scale row 26; lateral scale rows at fifth transverse ventral scale row $14 / 16$, at 10 th transverse ventral scale row $4 / 4$, at 15 th transverse ventral scale row $3 / 3$; lateral scales on body near insertion of forelimb small to granular; ventrals rectangular and juxtaposed; complete longitudinal ventral count 21 ; longitudinal ventral scale rows at midbody 12; 49 scales around midbody; anterior preanal plate scales two; posterior preanal plate scales four, all the scales at the same size; scales on tail rectangular and juxtaposed, keeled; at midventral subcaudals squarish.

Limbs pentadactyl; digits clawed; forelimb reaching anteriorly to fourth supralabial; dorsal brachial scales polygonal, of varying sizes, subimbricate, smooth; midbrachial anterodorsal scale at least twice as large as adjacent scales, smooth; anteroventral, ventral, and posteroventral scales roundish, imbricate, smooth; antebrachial scales polygonal, of various sizes; medial antebrachial scales small, rounded, smooth; dorsal manus scales polygonal, subimbricate; palmar scales small, oval, domelike; dorsal scales on fingers smooth, quadrangular, covering dorsal half of digit, overhanging supradigital scales, two on I, 5/4 on II, seven on III, nine on IV, five on V; subdigital scales $5 / 4$ on I, $10 / 9$ on II, thirteen on III, $14 / 15$ on IV, 7/8 on V; anterodorsal thigh scales polygonal, at least five times as large as adjacent scales, becoming smaller ventrally, smooth; posterodorsal thigh scales small, rounded, arranged irregularly; anterior and anteromedial shank scales polygonal, subimbricate, smooth, anteriormost scales many times larger than lateral, posterolateral, and posteromedial shank scales; lateral, posterolateral, and posteromedial shank scales polygonal or roundish, juxtaposed, smooth; dorsal pes scales polygonal, subimbricate, smooth; scales on dorsal surface of digits single, quadrangular, smooth, overhanging supradigital scales, two on I, five on II, eight on III, 10/10 on IV, 6/7 on V; subdigital scales single or double, 6/7 on I, 9/10 on II, 
$16 / 15$ on III, $22 / 21$ on IV, $10 / 11$ on V; femoral pores nine or 10 ; two scales between medialmost femoral pores.

The completely everted hemipenis is an acapitate organ without a medial welt; apex with two large protrusions separated by the distal end of the sulcus spermaticus; sulcus spermaticus single, flounces lacking calcified spines and forming two chevrons on distal half of hemipenis; sulcate flounces about as wide as asulcate flounces; asulcate flounces becoming shorter distally, three in the basal half and eleven in each protrusion, distal chevrons separated by a small expansion pleat; sulcus spermaticus single, flanked by a broad naked expansion pleat widened distally.

Coloration in preservative. Dorsal surface of head brown, dorsal surface of body and tail bluish brown with a middorsal dark bordered pale stripe on neck and body; lateral ocelli absent; ventral surfaces dirty white suffused with pale blue.

Coloration in life (Fig. 1a, d). Dorsal surface of head olive green; lateral surface of head, around the labial region yellowish orange with dark spots in each labial scale; ventral surface of head, pregular and gular region yellowish orange with dark grey spots on the genials and pregular scales. Dorsal surface of body same color as head, but with black spots in each scale around middorsal region, that form two indistinct and discontinous lines that extend from occiput to posterior hind limbs forming a dark bordered middorsal pale stripe; lateral surface of body same coloration as dorsum with one indistinct ocellus on both sides above insertion of forelimbs, some lateral scales bearing black or small orange spots; ventral surface of body reddish cream (resembling clay). Limbs similar to body, ventral surface of arms olive cream, ventral surface of legs cream. Coloration of dorsal and ventral surfaces of tail like that of body.

Variation (Fig. 1b-d). In the type series, the distinctness of the pale middorsal stripe is more noticeable in females than males, whereas the lateral stripes are obscure in some. Lateral ocelli are present forming a series from three to five ocelli on each side in females, and usually one on each side in males, only one male of the type series (CORBIDI 06967) has three ocelli on each side. Sexual dimorphism is evident in the size of the femoral pores, males have bigger femoral pores than females, but not in their number (8-11 in males versus 7-10 in females), however the main differences between females and males is the SVL (maximum SVL in females $=61.0 \mathrm{~mm}$, maximum SVL in males $=74.0 \mathrm{~mm}$ ). See Table 1 for variation in selected morphometric and squamation characters in the specimens examined.

Etymology. The specific epithet is based on the Quechua word "chasqui", which refers to the messengers of the Incan empire, men who, on foot, carried the messages throughout the imperial territory in the Cordillera de los Andes where these lizards are found.

Distribution and natural history. Euspondylus chasqui is known from two localities within a studied area of approximately $12 \mathrm{~km}^{2}$ in the Río Apurímac valley (Fig 4). It inhabits secondary forests and human settlements. The individuals observed were mostly found at midday under the rocks or foraging between stones, always near medium-sized rocks that they use for hiding. The soil under these rocks is generally more damp compared to the rest of the soil around. A clutch with two eggs was found 
Table I. Morphometric and pholidosis characters in E.chasqui and E.oreades. Individuals measured for $E$. chasqui include: eleven males, thirteen females, and a juvenile; for E. oreades: four males, eight females, and a juvenile. Range is followed by mean value and standard deviation in parenthesis.

\begin{tabular}{l|l|l|l}
\hline \multicolumn{2}{l}{} & Euspondylus chasqui $(\mathbf{n}=25)$ & Euspondylus oreades $(\mathbf{n}=13)$ \\
\hline \multirow{2}{*}{ Max SVL $(\mathrm{mm})$} & males & 74.0 & 61.0 \\
\cline { 2 - 4 } & females & 72.7 & 58.0 \\
\hline \multirow{2}{*}{ Tail length/SVL } & males & $1.2-2.1(1.6 \pm 0.3)$ & $1.0-1.8(1.4 \pm 0.3)$ \\
\cline { 2 - 4 } & females & $1.0-2.0(1.5 \pm 0.4)$ & $1.0-1.9(1.4 \pm 0.4)$ \\
\hline \multirow{2}{*}{ Head length/Head width } & males & $1.0-1.8(1.6 \pm 0.2)$ & $1.4-1.7(1.6 \pm 0.1)$ \\
\cline { 2 - 4 } & females & $1.6-2.0(1.9 \pm 0.1)$ & $1.4-2.0(1.7 \pm 0.2)$ \\
\hline \multirow{2}{*}{ Number of femoral pores } & males & $8-11(9.7 \pm 1.0)$ & $3-8(6.0 \pm 1.9)$ \\
\cline { 2 - 4 } & females & $8-10(9.1 \pm 0.5)$ & $2-8(5.8 \pm 2.3)$ \\
\hline Number of genials & $4(4.0 \pm 0.0)$ & $4(4.0 \pm 0.0)$ \\
\hline Number of postparietals & $3(3.0 \pm 0.0)$ & $3(3.0 \pm 0.0)$ \\
\hline Number of supratympanic temporals & $2-3(2.6 \pm 0.5)$ & $3(3.0 \pm 0.0)$ \\
\hline Number of scales around midbody & $20-28(23.2 \pm 2.4)$ & $20-25(22.7 \pm 1.8)$ \\
\hline Longitudinal dorsal count & $37-43(39.1 \pm 1.7)$ & $32-43(39.0 \pm 2.9)$ \\
\hline \multicolumn{2}{l}{ Number of longitudinal ventral scale rows } & $19-22(20.1 \pm 0.9)$ & $20-22(21.0 \pm 0.8)$ \\
\hline \multicolumn{2}{l}{ Number of transversal ventral scale rows } & $10-14(12.4 \pm 0.9)$ & $10-12(10.6 \pm 0.9)$ \\
\hline \multicolumn{2}{l}{ Lamellae under 4th finger } & $10-15(13.6 \pm 1.2)$ & $8-12(10.1 \pm 1.1)$ \\
\hline \multicolumn{2}{l}{ Lamellae under 4th toe } & $17-26(21.2 \pm 1.9)$ & $11-19(15.2 \pm 2.0)$ \\
\hline
\end{tabular}

under the litter, as well as several gravid females (CORBIDI 06955, 06966, 06968-69, 08417, 08420-21, 08424, 08431-32) from the dry and wet season (August and December, 2010) containing two eggs inside the abdominal cavity. This suggests that the maximum clutch size is two and that the reproductive cycle and birth of neonates can be at least twice a year. The egg length range is $3.4-14.1 \mathrm{~mm}(\bar{x}=8.3 \mathrm{~mm}, \mathrm{n}=20)$ and width range is $2.8-5.9 \mathrm{~mm}(\bar{x}=4.5 \mathrm{~mm}, \mathrm{n}=20)$, SVL range of gravid females is 48.5-72.7 $\mathrm{mm}$. We did not see nests sharing the same area. Euspondylus chasqui does not occur sympatrically with any other species of Euspondylus or Proctoporus; however, a marsupial frog, Gastrotheca rebeccae, was found at the same location. E. chasqui was the most abundant species in the type locality, where 35 individuals were found in four hours by four surveyers.

\section{Euspondylus oreades sp. $\mathbf{n}$.}

urn:Isid:zoobank.org:act:0C198ACA-83B5-46DF-8155-D0E31A084FBE http://species-id.net/wiki/Euspondylus_oreades

Figs 2-3

Holotype. (Fig 3.a-b) Adult male (CORBIDI 07219), Perú, Pasco Department, Santa Barbara $\left(10^{\circ} 20^{\prime} 29.1^{\prime \prime S} ; 75^{\circ} 38^{\prime} 27.1\right.$ 'W), at $3439 \mathrm{~m}$ of elevation, collected by Caroll Z. Landauro, Lesly Luján, Vilma Duran and Pablo J. Venegas on 23 September 2010. 

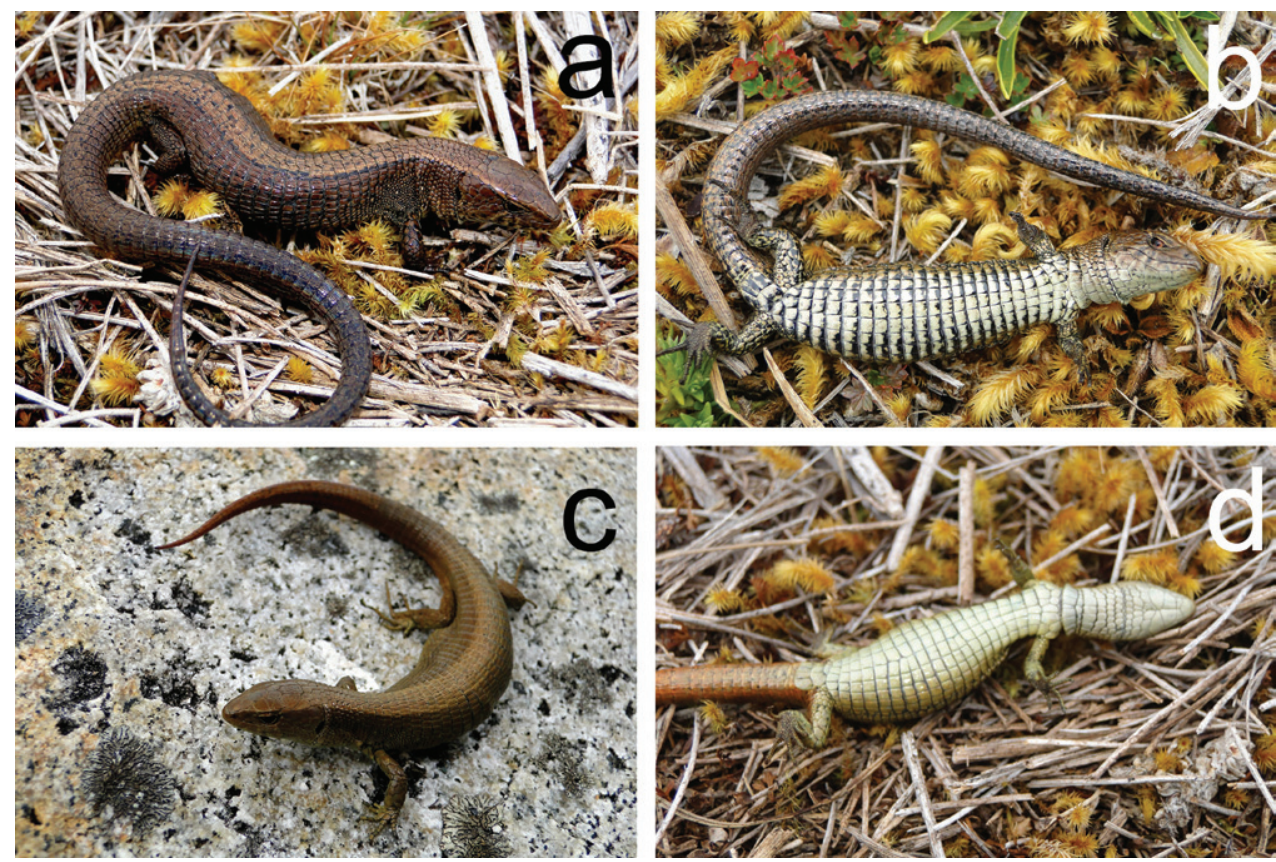

Figure 3. Euspondylus oreades, new species, from central Peru. Holotype male (CORBIDI 07219, a,b) and female (CORBIDI 07216, c,d).

Paratypes. CORBIDI 07214, 07216-18, 07220, 07222, 07224-25 (all females), 07215, 07221, 07229 (all males), 07223 (juvenile), same data as holotype.

Diagnosis. 1) Frontonasal length usually equal or slightly larger than frontal length; (2) nasoloreal suture present; (3) supraoculars four, anteriormost supraocular fused with anteriormost superciliary, all supraoculars separated from ciliaries; (4) superciliary series complete, four; (5) supralabial-subocular fusion absent; (6) postoculars three; (7) postparietals three; (8) supratympanic temporals three; (9) genials in two pairs, transverse sutures perpendicular with respect to midline of body; (10) dorsal scales quadrangular, juxtaposed, keeled; (11) transverse dorsal count (enlarged rows at midbody) at midbody 20-26 in both sexes; (12) longitudinal dorsal count 37-43 in both sexes; (13) longitudinal ventral count 20-22 in both sexes; (14) lateral scale rows at midbody two; (15) femoral pores in males 3-8, in females $2-8$; two scales between femoral pores; (16) subdigital scales on 4th finger 5-13, on 4th toe 10-19; (17) limbs overlapping, pentadactyl; digits clawed; forelimb reaching anteriorly to fourth supralabial; (18) anterior preanal plate scales paired; (19) hemipenis acapitate; flounces forming two chevrons on distal half of hemipenis whereas basal half is covered with one or two transverse flounces; asulcate flounces separated by a small expansion pleat; sulcate flounces about as wide as asulcate flounces; sulcus spermaticus single, flanked by a broad naked expansion pleat widened distally and divided by a small protrusion; (20) dorsum brown or pale brown with a middorsal pale stripe bordered by an discontinous dark line on neck and body; lateral ocelli usually absent; ventral surfaces 
white or creamy white; (21) transparent lower palpebral disc an undivided oval; (22) prefrontals usually present.

Euspondylus oreades can be distinguished from the Peruvian species of Euspondylus by the following character states (condition for E. oreades in parentheses). E. maculatus and E. guentheri: lower palpebral disc with vertical sections (palpebral disc an undivided oval), dorsal scales smooth or wrinkled (keeled), and longitudinal dorsal count 32-37 (36-43). E. caideni: maximum SVL $=82.0 \mathrm{~mm}(61.0 \mathrm{~mm})$, pale middorsal stripe absent (present), dorsal scales reduced in size above longitudinal band of laterals granules (not reduced), longitudinal dorsal count 41-48 (36-43). E. josyi: pale middorsal stripe absent (present), supraoculars three, exceptionally four (always four) limb overlapping 10-13 dorsal scales (10-11) and longitudinal dorsal count 29-35 (36-43). E. rahmi: anteriormost supraocular not fused with anterior most superciliar (fused), dorsal scales reduced in size above longitudinal band of lateral granules (not reduced), longitudinal dorsal count 49-54 (36-43) and maximum SVL to $71.0 \mathrm{~mm}(61.0 \mathrm{~mm})$. E. simonsii: a pale line between the tympanum and shoulder present (absent), dorsal scales smooth or only faintly keeled on posterior dorsum (all dorsal scales keeled), transversal count at midbody less than 35 scales (40-46) and longitudinal dorsal count 33-39 (36-43). E. spinalis: head acuminate from dorsal and lateral view (rounded), dorsal scales reduced in size above longitudinal band of lateral granules (not reduced), subdigital lamellae of fourth toe 20-24 (11-19), longitudinal dorsal count 39-46 (32-43), femoral pores on one side in females 1-6 (4-8), supracaudal scales only faintly keeled or smooth (strongly keeled) and lateral ocelli usually present (usually absent). E. nellycarrillae: dorsal scales subhexagonal (rectangular), longitudinal dorsal count 41-49 (36-43) femoral pores of one side 12-15 in males, 12-14 in females (6-8 in males, 2-5 in females). E. chasqui: superciliar series five (four), subdigital scales on the fourth toe 17-26 (13-19), femoral pores of the one side 8-11 in males, 7-10 in females (6-8 in males, 2-5 in females) and maximum SVL $=74.0 \mathrm{~mm}(61.0 \mathrm{~mm})$.

Euspondylus oreades can be distinguished from all species currently assigned to Petracola, Proctoporus, and Riama by the presence of prefrontal scales (absent in all species in these three genera). E. oreades can be further distinguished by the following character states (condition for E. oreades in parentheses) from all Bolivian and Peruvian species of Proctoporus except $P$. pachyurus and $P$. bolivianus: longitudinal dorsal count fewer than 36 scale rows (37-43 scale rows). P. pachyurus: longitudinal dorsal count 49-59 (37-43). P. bolivianus: four or five supralabials (six or seven). All Petracola and Riama species: lower palpebral disc with vertical sections (palpebral disc an undivided oval). All northern Ecuadorian Riama species except $R$. columbiana: no band of granular scales along the sides of body between dorsal and ventral scales (granular scales present). $R$. columbiana: limbs not overlapping when adpressed against body in adults (limbs overlapping), superciliary series incomplete (complete), and some supraoculars in contact with ciliaries (all supraoculars separated from ciliaries).

Euspondylus oreades can be distinguished from Opipeuter xestus (condition for $E$. oreades in parentheses): smooth dorsal scales (keeled); having a single large elongate subocular scale (several small subocular scales); and in hemipenis morphology, large spines at the base of the sulcus spermaticus (no such spines present in E. oreades). 
Description of the holotype. Adult male (CORBIDI 07219) (Fig. 2c,d; 3a,b); SVL $55.0 \mathrm{~mm}$, tail (complete) length $101.0 \mathrm{~mm}$; axilla to groin distance $26.7 \mathrm{~mm}$; head length $13.2 \mathrm{~mm}$; head width $8.8 \mathrm{~mm}$; shank length $7.2 \mathrm{~mm}$. Head scales smooth, glossy; rostral scale wider $(2.4 \mathrm{~mm})$ than long $(1.4 \mathrm{~mm})$, slightly higher than adjacent supralabials, in contact with frontonasal, nasoloreal, and first supralabials posteriorly; frontonasal wider $(2.8 \mathrm{~mm})$ than long $(2.6 \mathrm{~mm})$, widest posteriorly, in contact with nasoloreal and frenocular laterally, prefrontals posteriorly; nasoloreal suture present; prefrontals present, in contact with each other medially, in contact with fused anteriormost superciliary-anteriormost supraocular, frontal posteriorly; frontal slightly longer $(2.3 \mathrm{~mm})$ than wide $(2.2 \mathrm{~mm})$, anterior suture angular with point directed anteriorly, lateral sutures straight, posterior suture angular with point directed posteriorly, in contact with second and third supraocular laterally, frontoparietals posteriorly; frontoparietals pentagonal, in contact with third and fourth supraocular, parietals and interparietal posteriorly; supraoculars four, none in contact with ciliaries; superciliary series complete, anteriormost superciliary fused with anteriormost supraocular; interparietal pentagonal, longer $(3.2 \mathrm{~mm})$ than wide $(1.7 \mathrm{~mm})$, in contact with parietals laterally, postparietals posteriorly; parietals pentagonal, in contact with fourth supraocular anterolaterally, temporal scales laterally, dorsalmost postocular, postparietals posteriorly; postparietals three, lateral postparietals pentagonal, medial postparietal squarish; palpebral disc an undivided oval, unpigmented; frenocular quadrangular, in contact with nasoloreal anteriorly; postoculars three; temporals polygonal; supratympanic temporals three; supralabials eight; infralabials seven; mental wider $(2.3 \mathrm{~mm})$ than long $(1.4 \mathrm{~mm})$, in contact with first infralabials, postmental posteriorly; postmental single, pentagonal, posterior suture angular, point directed posteriorly, in contact with first and second infralabials; genials in two pairs, both pairs subquadrangular, in contact with second and third infralabials; posterior genials subpentagonal, in contact with fourth and fifth infralabials laterally; scale rows between genials and collar fold (along midventral line) 10; medialmost scales of three penultimate gular scale rows slightly enlarged; posteriormost gular row enfolded posteriorly, concealing two granular scale rows; lateral neck scales rounded, smooth.

Dorsal scales quadrangular, longer than wide, juxtaposed, keeled, 42 in a longitudinal count; some middorsal scales irregularly arranged; transverse dorsal count (enlarged rows at midbody) at fifth transverse ventral scale row 8, at 10th transverse ventral scale row 11 , at 15 th transverse ventral scale row 11 ; lateral scale rows at fifth transverse ventral scale row $13 / 12$, at 10 th transverse ventral scale row two, at 15 th transverse ventral scale row two; lateral scales on body near insertion of forelimb small to granular; ventrals rectangular and juxtaposed; one complete longitudinal at ventral count 22; longitudinal ventral scale rows at midbody 12; 29 scales around midbody; anterior preanal plate scales six; posterior preanal plate scales four (third one not totally developed), all the scales at the same size; scales on tail rectangular and juxtaposed, keeled; midventral subcaudals squarish.

Limbs pentadactyl; digits clawed; forelimb reaching anteriorly to fourth supralabial; dorsal brachial scales polygonal, of varying sizes, subimbricate, smooth; midbra- 
chial anterodorsal scale at least twice as large as adjacent scales, smooth; anteroventral, ventral, and posteroventral scales roundish, imbricate, smooth; antebrachial scales polygonal, of various sizes; medial antebrachial scales small, polygonal, smooth; dorsal manus scales polygonal, subimbricate; palmar scales small, oval, domelike; dorsal scales on fingers smooth, quadrangular, covering dorsal half of digit, overhanging supradigital scales, two on I, five on II, five on III, six on IV, four on V; subdigital scales four on I, seven on II, 9/10 on III, 7/8 on IV, seven on V; anterodorsal thigh scales polygonal, at least two times as large as adjacent scales, becoming smaller ventrally, smooth; posterodorsal thigh scales small, rounded, arranged irregularly; anterior and anteromedial shank scales roundish, subimbricate, smooth, anteriormost scales many times shorter than lateral, posterolateral, and posteromedial shank scales; lateral, posterolateral, and posteromedial shank scales polygonal or roundish, juxtaposed, smooth; dorsal pes scales polygonal, subimbricate, smooth; scales on dorsal surface of digits single, quadrangular, smooth, overhanging supradigital scales, two on I, 4/5 on II, eight on III, ten on IV,seven on V; subdigital scales single or double, four on I, nine on II, 12/13 on III, seventeen on IV, nine on V; femoral pores seven or eight; two scales between medial most femoral pores.

The completely everted hemipenis is an acapitate organ without a medial welt; apex with two large protrusions separated by the distal end of the sulcus spermaticus; sulcus spermaticus single, flounces lacking calcified spines and forming two chevrons on distal half of hemipenis; sulcate flounces about as wide as asulcate flounces; asulcate flounces becoming shorter distally, two in the basal half and ten, in each protrusion, distal chevrons separated by a small expansion pleat; sulcus spermaticus single, flanked by a broad naked expansion pleat widened distally.

Coloration in preservative. Dorsal surfaces of head, body, and tail brown with a middorsal dark bordered pale stripe on neck; bearing three lateral ocelli in both sides; ventral surface bluish white with black blotches in each scale, ventral surface of the hind limbs and forelimbs pale brown.

Coloration in life (Fig. 3a,b). Dorsal surface of head pale brown; lateral surface of head dark brown, dark and white spots in each labial scale forming labial bars; ventral surface of head creamy white with irregular line on postmental, genials and post genials scales, pregular and gular region creamy white. Dorsal surface of body, on the middorsal region same color as head, but with black blotches in each middorsal scale bordering the middorsal region and forming a dark bordered pale stripe from the occipital region to the posterior insertion of the hind limbs; lateral surface of body dark brown with three ocelli above insertion forelimbs on both sides, some lateral granular scales white and some keeled lateral scales bearing black blotches; ventral surface of body creamy with with black blotches. Limbs similar to body, ventral surface of arms cream with dark spots, ventral surface of legs cream with black blotches. Coloration of dorsal and ventral surfaces of tail like that of body.

Variation. In the type series, the distinctness of the pale middorsal stripes varies. However, at least the bordered stripes are visible in all specimens, whereas the lateral stripes are obscure in some, only CORBIDI 07216, is lacking the bordered stripe (Fig. 
3c,d). Lateral ocelli are not present in most of the specimens except CORBIDI 07219 (three ocelli on both sides), 07221 and 07229 (both specimens with a row of ocelli on both sides). Sexual dimorphism is evident in the size of the femoral pores (bigger in males than in females) and in their number (2-5 in females versus 6-8 in males). See Table 1 for variation in selected morphometric and squamation characters in the specimens examined.

Etymology. The specific name oreades refers to the Oreades, nymphs of Greek mythology. These feminine spirits lived and protected isolated mountains and caves, places that recall the type locality where this species was found.

Distribution and natural history. Euspondylus oreades is known only from the type locality, an isolated hill at an elevation of $3400 \mathrm{~m}$ in the Cordillera Oriental in central Peru, inside Yanachaga-Chemillen National Park (Oxapampa Bioesphere Reserve) (Fig. 4). Individuals were found in grassland (Puna habitat) under rocks, fallen trunks, moss, and under the base of terrestrial spiny bromeliad (Puya sp.) by the day. Only the marsupial frog Gastrotheca griswoldi was found sympatric with $E$. oreades. A total of 33 individuals of $E$. oreades were found in seven hours of survey by four herpetologists. Four nests of the new species of Euspondylus were found under the rocks and the number of eggs found per nest vary from two to 15 . Two eggs of $E$. oreades hatched during the surveys and the new hatchlings ran to hide immediately after leaving the egg shell. One of these hatchlings was collected (CORBIDI 07223) and measured $(\mathrm{SVL}=23.0 \mathrm{~mm})$. Six females were collected, five of them contained eggs in their oviducts, only CORBIDI 07216 contained one egg, the rest of mature females contained two eggs, SVL range of these specimens was $53.0-61.0 \mathrm{~mm}$. Egg length ranged from $3.2-13.2 \mathrm{~mm}(\bar{x}=8.6 \mathrm{~mm}, \mathrm{n}=9)$ and width ranged from $3.6-5.7 \mathrm{~mm}(\bar{x}=3.7 \mathrm{~mm}$, $\mathrm{n}=9$ ). The ornithological team in Santa Barbara collected one Variable Hawk Buteo polyosoma (CORBIDI/FHC 245) that contained three whole E. oreades individuals in the crop and the remains of three other individuals in the stomach. Furthermore, the team collected one Andean Caracara Phalcoboenus megalopterus (CORBIDI/WV 315) with remains of an unassigned Euspondylus species in its stomach. These findings could suggest that these lizards can be found in the open, but for $E$. oreades we did not have such observations. However, one of us (GC) found E. chasqui running between stones when sampling, which might be a behavior that could occur in $E$. oreades as well.

Remarks. Most of the Euspondylus species occur on, isolated points in the Andes (Kizirian 1996; Köhler 2003; Köhler and Lehr 2004), in montane forests or transition areas between montane forests and grasslands. Several genera from the families Gymnophthalmidae and Iguanidae have been recorded in the high Andes (Fritts 1972; Cadle 1991; Laurent 1992; Laurent 1998). Of these Anadia, Euspondylus, Petracola, Pholidobolus, Proctoporus and Riama (Gymnophthalmidae) and Stenocercus and Liolaemus (Iguanidae) are the only genera found above 3000 meters of elevation.

Both species described in this paper, Euspondylus chasqui and E. oreades, are abundant at their respective type localities and, where surveyed, are not sympatric with any other lizard species. The only species that is distributed close to Euspondylus oreades is E. spinalis (Fig. 2 e,f). Even though there is no natural history data published for E. spi- 


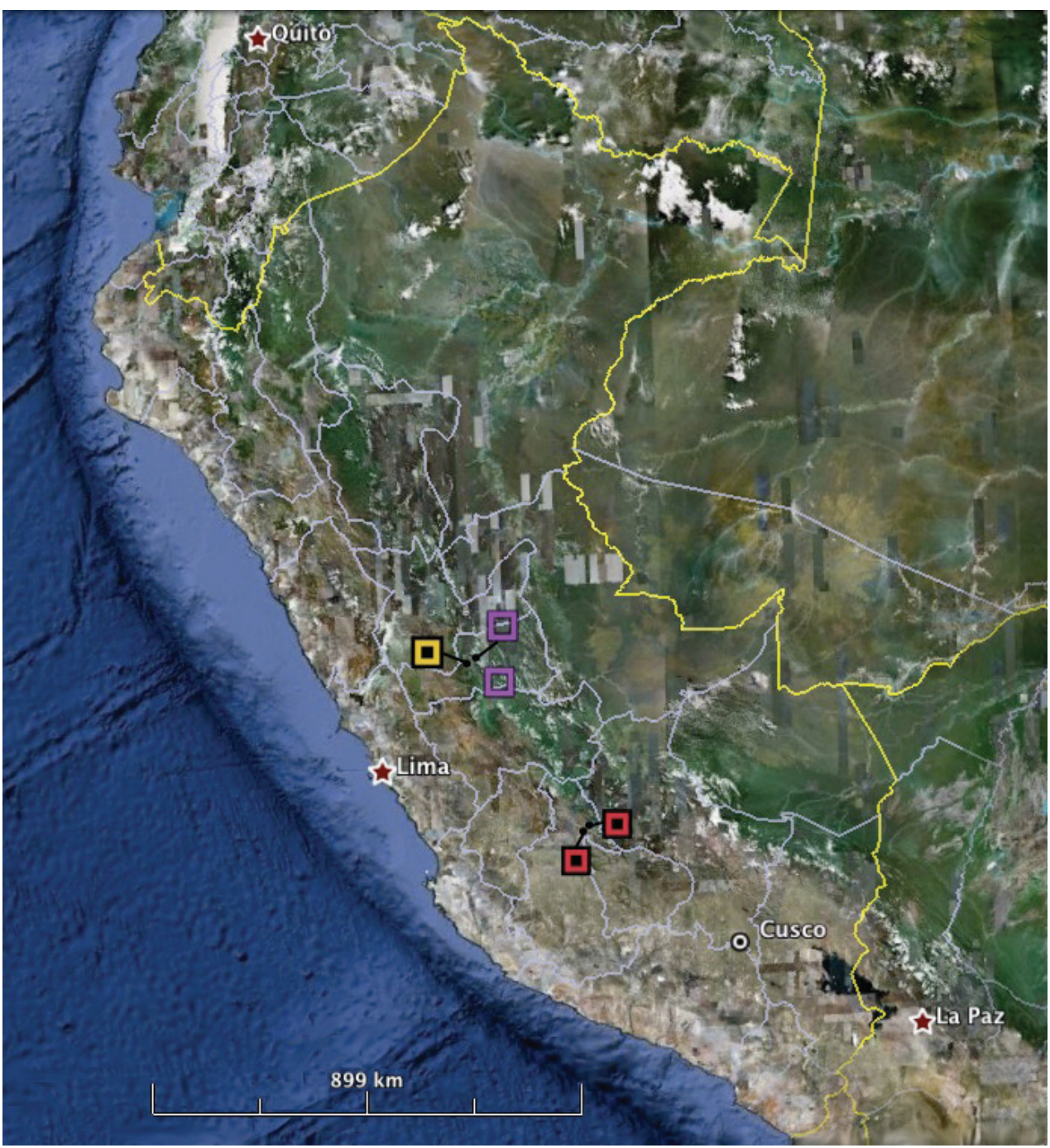

Figure 4. Map showing distributions of the new Euspondylus species. The filled-in squares represent records for both new species. Red filled-in squares correspond to $E$. chasqui and yellow filled-in square corresponds to E. oreades. Purple empty squares correspond to E. spinalis.

nalis, we have observed that the latter occurs in montane habitats, while E. oreades occurs in grasslands. We have also found that E. spinalis, was the most abundant species at two localities: Chacos Community (10³5'24.2" S, 75¹6'24.4” W, $1986 \mathrm{~m}$ ) and Oso Playa Road (10¹9'21.5” S, 75³5'03.1” W, 2000 m), in the Pasco Department (Fig. 4), with 14 individuals found in two hours by one surveyer and 87 individuals in two hours by two surveyers, respectively. Only in Chacos did we find E. spinalis in sympatry with the iguanid lizard Stenocercus boettgeri, even though, S. boettgeri was not abundant (only three individuals recorded). Given the high abundances observed of 
these gymnophthalmid lizards, it is likely that they play an important role in the lizard community composition, and apparently, in the trophic chain of certain major predators, as evidenced by the records of Euspondylus lizards found in the stomach contents of Buteo polyosoma and Phalcoboenus megalopterus.

\section{Acknowledgments}

We would like to thank Gunther Köhler and Tiffany Doan for their constructive comments that improved the manuscript during its review. GC and KS thank Pedro Nunes for providing useful comments in gymnophthalmid taxonomy and literature for the present work. For allowing access to herpetological collections we are grateful to Jesús Córdova and César Aguilar (MUSM). GC is very grateful to Programa de Monitoreo Biológico COGA and Knight Piesold Consultores S.A. for their support to carry out fieldwork, to Karla García for her assistance during fieldwork, to Alfredo Mayta and Jaime Valenzuela for their logistic support in the field and to Joaquin Ugarte and Edgardo Enriquez for trusting the work of GC. PV and VD are indebted to the following persons and institutions: the staff of the Servicio Nacional de Áreas Naturales Protegidas por el Estado (SERNANP), especially the rangers and volunteers for their cooperation and for the research permits; Luis Ríos from Consultores Asociados en Naturaleza y Desarrollo (CANDES), Willy Nañez of CORBIDI for the logistic support in the field; and Daniel Matos and Abel Orihuela from Ministerio del Ambiente (MINAM) for the coordinations with SERNANP. Field work of PV and VD was funded by MINAM.

\section{References}

Cadle JE (1991) Systematics of lizards of the genus Stenocercus (Iguania:Tropiduridae) from northern Peru. New species and comments on relationships and distribution patterns. Proceedings of the Academy of Natural Sciences of Philadelphia 143: 1-96.

Doan TM, Castoe TA (2003) Using morphological and molecular evidence to infer species boundaries within Proctoporus bolivianus Werner (Squamata: Gymnopthalmidae). Herpetologica 59: 432-449. doi:10.1655/03-09

Doan TM, Castoe TA (2005). Phylogenetic taxonomy of the Cercosaurini (Squamata: Gymnophthalmidae), with new genera for species of Neusticurus and Proctoporus. Zoological Journal of the Linnean Society 143: 405-416. doi:10.1111/j.1096-3642.2005.00145.x

Fritts TH (1972) New species of lizards of the genus Stenocercus from Peru (Sauria: Iguanidae). Occasional Papers of the Museum of Natural History, University of Kansas 10: 1-21.

Kizirian D (1996) A review of Ecuadorian Proctoporus (Squamata: Gymnophthalmidae) with descriptions of nine new species. Herpetological Monographs 10: 85-155. doi: $10.2307 / 1466981$ 
Köhler G (2003) Two new species of Euspondylus (Squamata: Gymnophthalmidae) from Peru. Salamandra 39: 5-20.

Köhler G, Lehr E (2004) Comments on Euspondylus and Proctoporus (Squamata: Gymnophthalmidae) from Peru, with the description of three new species and a key to the Peruvian species. Herpetologica 60: 501-518. doi:10.1655/03-93

Laurent R (1992) On some overlooked species of the genus Liolaemus Weigmann (Reptilia: Tropiduridae) from Peru. Breviora 494: 1-33.

Laurent R (1998) New forms of lizards of the subgenus Eulaemus of the genus Liolaemus (Reptilia: Squamata: Tropiduridae) from Peru and northern Chile. Acta Zoológica Lilloana 44: $1-26$.

Mijares-Urrutia A, Celsa Señaris J, Arends A (2001) Taxonomía de algunos microteidos (Squamata) de Venezuela I: Variación y distribución geográfica de Euspondylus acutirostris con la descripción de un nuevo Euspondylus. Revista de Biología Tropical 48: 671-680.

Montanucci R (1973) Systematics and evolution of the Andean lizard genus Pholidobolus (Sauria: Teiidae). University of Kansas, Museum of Natural History, Miscellaneous Publication 59: $1-52$.

Peters J, Donoso-Barros R (1970) Catalogue of the Neotropical Squamata. Part II. Lizards and Amphisbaenians. United States National Museum Bulletin 297: 1-293.

Pianka E, Vitt L (2003) Lizards: Windows to the Evolution of Diversity. University of California Press, Berkeley, 348 pp.

Presch W (1980) Evolutionary history of the South American microteiids lizards (Teiidae: Gymnophthalminae). Copeia 1980: 36-56. doi:10.2307/1444132 